\title{
A survey of Italian compost dairy barns
}

\author{
Lorenzo Leso, ${ }^{1}$ Maurizio Uberti, ${ }^{2}$ Wasseem Morshed, ${ }^{1}$ Matteo Barbari ${ }^{1}$ \\ ${ }^{1}$ Department of Agricultural, Food and Forestry Systems, University of Florence; \\ ${ }^{2}$ Freelance veterinary surgeon, Mantua, Italy
}

\begin{abstract}
Compost-bedded pack barns (CBPB), generally known as compost dairy barns, are alternative housing systems for dairy cows. In these barns, the whole surface of the resting area is covered with a deepbedded pack that is frequently stirred in order to incorporate fresh manure into the pack and to enhance the evaporation of water. Experiences with CBPB for dairy cows are reported in literature from the US, Israel, the Netherlands and Austria. Potential advantages of these housing systems regard animal welfare and manure management. Since 2006, this housing system has been widely applied in Italy. However, there is still little scientific knowledge available about Italian CBPB. This study aims to describe the housing system, assess producers' satisfaction and measure performance of dairy cows housed in CBPB. Ten commercial dairy farms in northern Italy were involved in the study. All pens in each farm were surveyed to determine the total available surface area, bedded area and pack depth. A questionnaire was submitted to each farm manager in order to investigate management practices, labour requirement, amount of bedding materials used and producers' satisfaction. The temperature of the bedded pack was measured in summer and in winter. Data from the Italian Dairy Association were collected for each herd over a period of one year (from September 2011 to September 2012). In the barns involved in the study, the average total available area was $10.9 \mathrm{~m}^{2} / \mathrm{cow}$ and the average pack area was
\end{abstract}

Correspondence: Lorenzo Leso, Department of Agricultural, Food and Forestry Systems, University of Florence, via San Bonaventura 13, 50145 Florence, Italy.

E-mail: lorenzo.leso@unifi.it

Key words: compost-bedded pack, dairy cows, loose housing system, management.

Acknowledgements: the authors wish to thank all the dairy producers involved in the study for their kind collaboration. They also thank the Associazione Italiana Allevatori and the APA of Mantua and Cremona for their important contribution in providing data.

Received for publication: 30 September 2013.

Accepted for publication: 20 November 2013.

(C) Copyright L. Leso et al., 2013

Licensee PAGEPress, Italy

Journal of Agricultural Engineering 2013; XLIV:e17

doi:10.4081/jae.2013.e17

This article is distributed under the terms of the Creative Commons Attribution Noncommercial License (by-nc 3.0) which permits any noncommercial use, distribution, and reproduction in any medium, provided the original author(s) and source are credited.
$6.7 \mathrm{~m}^{2} /$ cow. The bedded pack was aerated 1.4 times per day.

The most commonly used bedding material in these farms was dry sawdust. The consumption of bedding materials was $8.1 \mathrm{~m}^{3} / \mathrm{cow}$ per year. A tendency towards inverse correlation was found between the space per cow and the amount of bedding needed per cow $\left(\mathrm{R}^{2}=0.395\right.$; $\mathrm{P}=0.051$ ). Operations related to pack management required 4.1 hours of labour per cow per year. A direct relationship was found between the bedded area space per cow and the annual labour required for pack management $\left(\mathrm{R}^{2}=0.505 ; \mathrm{P}=0.048\right)$. Although some concerns were raised about the cost of bedding and ease of management, producers were satisfied with this housing system.

\section{Introduction}

Compost-bedded pack barns (CBPB), generally known as compost dairy barns, are an alternative loose housing system that appears to offer an excellent level of comfort for dairy cows. In this type of barn, cows are provided with a large bedded area for resting rather than individual stalls. Compost-bedded pack refers to a mixture of faeces and urine produced by the cows and organic bedding. Unlike conventional straw-bedded yards, the whole surface of compost packs is worked once or twice daily to dry the surface and incorporate manure into the pack (Klaas and Bjerg, 2011). A properly managed bedded pack provides a dry, comfortable and healthy surface on which cows lie, stand and walk. CBPB are to be found throughout the US, Israel, Europe and South Korea (Galama, 2011). An analysis of the international literature identified two main types of CBPB. Although both types seem to be based on the evaporation of water from the pack, management practices, type of bedding materials and barn characteristics differ significantly (Galama, 2011; Klaas and Bjerg, 2011).

The first type, which was initially developed in the US and applied with some modifications also in the Netherlands and Austria, is based on the development of heat in the pack. In this type of CBPB, the most important factor is to maintain adequate chemical and physical characteristics in the substrate in order to promote aerobic microbial activity (Black et al., 2013). The recommended bedded area space per cow for this type of housing system ranges from 7.4 to $12.5 \mathrm{~m}^{2} / \mathrm{cow}$ (Janni et al., 2007; Galama, 2011). The most commonly used bedding materials are sawdust, wood shavings and wood chips. Black et al. (2013) found that maximum pack temperatures in this kind of CBPB tend to be achieved when the bed moisture content is between $40 \%$ and $60 \%$. The second type of CBPB takes advantage of the natural drying potential of the air rather than heat production within the pack (Galama, 2011). This type of housing system has been developed in Israel and is the object of increasing interest in the Netherlands. The recommended bedded area space per cow in this type of CBPB ranges from 15 to $20 \mathrm{~m}^{2} /$ cow in barns provided with scraped feeding alleys and up to 30 $\mathrm{m}^{2} /$ cow in systems without concrete alleys (Klaas et al., 2010).

In Italy, since 2006, use of CBPB has spread; currently, there are around $50 \mathrm{CBPB}$, mostly located on the Po Plain, northern Italy (M 
Uberti, personal communication, 2012). Although in other countries this housing system has evolved mainly with the aim of improving the welfare of dairy cows (Barberg et al., 2007a; Klaas et al., 2010), in Italy it was initially developed to reduce the risk of mastitis in deep strawbedded yards. Italian farmers soon saw the advantages in the compostbedded pack in terms of udder health (Vighi et al., 2009). A few years later, also the positive effects on the prevalence of lameness and longevity became evident, and many more farmers shifted to using CBPB. As a matter of fact, one of the most noticeable benefits of CBPB regards cow comfort and feet and leg health (Ofner-Schröck et al., 2013; Barberg et al., 2007b; Fulwider et al., 2007). Lobeck et al. (2011) found that dairy cattle housed in CBPB had reduced lameness and hock lesions compared with those housed in free stall barns. Observations of lying behaviour, social interactions, and natural lying positions indicated that CBPB could be an adequate housing system for dairy cows (Enders and Barberg, 2007). Besides the benefits concerning animal welfare, if correctly managed, this alternative housing system can have other advantages: better stability of obtained compost; high agronomic value; minimises unpleasant odours; fewer flies; produces less wastewater; reduces costs of manure storage; uses byproducts and scraps as bedding.

Although producers from the US were satisfied with CBPB they expressed some concerns regarding pack management and the availability of bedding (Shane et al., 2010). As a matter of fact, the main disadvantages of this alternative housing system seemed to be the high cost of bedding (especially sawdust) and the labour and the energy needed for pack stirring. Another issue related to CBPB regards gaseous emission from the pack. The wide surface area and the frequent mixing could result in high ammonia volatilisation (van Dooren et al., 2012). Dutch researchers compared ammonia emissions from CBPB and free stall barns and showed that, although in CBPB the emission per square metre was significantly lower, the larger surface area led to a slightly higher amount of ammonia being released per animal (Galama, 2011).

In recent years, Italian dairy farmers have shown a growing interest in CBPB (Ventura, 2011; Leso et al., 2013). However, there is still little scientific knowledge available about Italian CBPB. The objective of the current study was to describe housing system and management practices, assess producers' satisfaction, and measure performance of dairy cows housed in Italian CBPB.

\section{Materials and methods}

This observational study was performed on 10 dairy farms in the provinces of Mantua $(n=7)$ and Cremona $(n=3)$, northern Italy. All farms included met the following criteria: changed to CBPB at least two years before the start of the study; all lactating cows were housed in $\mathrm{CBPB}$; the pack was cultivated at least once a day; total mixed ration feeding system was used for lactating cows.

The primary breed in all farms was Holstein. Monthly dairy herd records were obtained from the Italian Dairy Association (Associazione Italiana Allevatori, Rome, Italy) for each farm included in the study. To assess herd performance, the following data were collected over a period of one year (from September 2011 to September 2012): herd mean daily milk yield; 305 mature equivalent milk production; days in milk; fat and protein content; herd mean somatic cell count (SCC); age at first calving; mean number of parity; calving interval; mean number of services per pregnancy.

Each farm was visited once between July and September 2012 to collect on-site data that included: barn dimensions and layout; total available surface area per cow; lying surface area per cow; bedding type and pack depth.

Barn dimensions were measured using a Leica DIST0 A5 laser distance meter (Leica Geosystems, Heerburgg, Switzerland). A questionnaire was given to the herd manager at the time of the visit. The first part of the questionnaire included 25 questions regarding pack management practices, machinery and equipment used, labour required and consumption of bedding. In the second part of the questionnaire, producers were asked to express their satisfaction with the housing system with regards to animal welfare, cow cleanliness, udder health, claw and leg health, fertility, longevity, milk yield, ease of management, costs and manure management. Satisfaction levels was expressed using a 4-point scale where 1 =very dissatisfied, $2=$ dissatisfied, $3=$ satisfied and $4=$ very satisfied.

In addition, 5 farms were visited twice, once in winter (January 2012) and once in summer (August 2012), to measure the temperature of the pack and the air temperature inside the barn. Pack temperatures were taken at ten points across the resting area at a depth of $20 \mathrm{~cm}$. Air temperature was measured in five positions inside the barn at $1 \mathrm{~m}$ above the pack surface. Temperature was measured by the same operator using a D0 9847 portable multifunction data-logger (Delta Ohm, Padua, Italy).

\section{Statistical analysis}

Descriptive statistics (mean, SD and range) were used to describe herd characteristics, surface area per cow, pack depth, pack temperatures, air temperatures, quantitative data regarding management practices, and producer satisfaction scores. Results are presented as mean \pm SD and range. Linear regression analyses were performed to identify variables affecting consumption of bedding and labour requirement. Residuals were visually checked. Coefficient of determination $\left(R^{2}\right)$ was calculated to assess the goodness of fit of the model and a $t$ test was performed to determine whether there is a significant linear relationship between variables. All analyses were performed using the Base and Stats packages of R (R Development Core Team, 2011).

\section{Results}

Herds included in this study numbered $112 \pm 58.8$ lactating cows (range 42-192). Descriptive statistics for the herd performance are reported in Table 1. All the barns had a flat concrete floor under the bedded pack and 9 barns had an indoor $(n=6)$ or outdoor $(n=3)$ scraped

Table 1. Herd performance between September 2011 and September 2012.

\begin{tabular}{lccc} 
& Min & Mean (SD) & Max \\
Milk yield, kg/cow/day & 24.8 & $30.8(3.05)$ & 35.2 \\
DIM & 184 & $209(29.1)$ & 273 \\
\hline 305 mature equivalent milk production, $\mathrm{kg}$ & 9205 & $10541(667)$ & 11458 \\
Milk fat, \% & 3.43 & $3.67(0.17)$ & 3.88 \\
\hline Milk protein, \% & 3.33 & $3.48(0.10)$ & 3.62 \\
SCC, cell/1000/mL & 132 & $354(121.1)$ & 548 \\
\hline Age at first calving, months & 22 & $29(4.0)$ & 35 \\
No. parity & 2.01 & $2.39(0.26)$ & 2.74 \\
\hline Calving interval, days & 395 & $450(35)$ & 494 \\
No. services per pregnancy & 1.84 & $2.67(0.47)$ & 3.53 \\
\hline
\end{tabular}

SD, standard deviation; DIM, days in milk; SCC, somatic cell count. 
feed alley. Feed alleys were $4.32 \pm 1.54 \mathrm{~m}$ wide while the space per cow at the feed fence was $0.58 \pm 0.20 \mathrm{~m} /$ cow. One barn did not have a scraped alley. Total available surface area per cow was $11.0 \pm 4.1 \mathrm{~m}^{2} / \mathrm{cow}$. The resting area (compost-bedded pack) per cow was $6.8 \pm 2.2 \mathrm{~m}^{2} / \mathrm{cow}$ (range 3.56-10.18 $\mathrm{m}^{2} / \mathrm{cow}$ ). At the moment of farm visits the bedded pack was $25.6 \pm 9.4 \mathrm{~cm}$ deep (range $15-40 \mathrm{~cm}$ ).

\section{Management}

The most commonly used management practice applied in CBPB in this study starts with preparation of a compost-bedded pack. To do this, a layer of $10-20 \mathrm{~cm}$ of organic bedding is distributed on the floor of the lying area. During the first 5-10 days, the pack is not aerated and no bedding is added. After this start period, the surface of the bedded pack is stirred on a regular basis once or twice daily while cows are being milked in the parlour. A layer of fresh dry bedding is added every $12 \pm 17$ days. Most producers add a consistent amount of fresh dry materials only when the bedding particles start to adhere to the cows, but in some dairies a smaller amount is added more frequently, up to once daily. Over the year, the bedded pack area is completely cleaned out every $30 \pm 35$ days (range 10-90 days) when the moisture content of the bedded pack exceeds a critical level at which cows start to sink deep into the pack and aeration becomes difficult.

In 6 farms, the pack was aerated once a day and twice a day in the remaining 4; average 1.4 aerations per day. Typically, a tractor provided with a tine cultivator was used to stir the bedded pack. Tractors used to cultivate the pack had $62 \pm 16.1 \mathrm{~kW}$ horsepower (range $37-88 \mathrm{~kW}$ ). $0 \mathrm{n}$ average, the pack was aerated at a depth of $19 \pm 7.6 \mathrm{~cm}$ (range 10-30 $\mathrm{cm})$. Stirring the pack required $41 \pm 47 \mathrm{~min} /$ day (range $5-150 \mathrm{~min} /$ day) and resultant productivity was $2610.9 \pm 2425.7 \mathrm{~m}^{2} / \mathrm{h}$ (range $725-8006.5$ $\mathrm{m}^{2} / \mathrm{h}$ ). All the operations related to compost-bedded pack management (start-up, aeration, adding bedding and barn cleaning) required $356 \pm 274 \mathrm{~h} /$ year (range 136-1002 h/year). A comparison of the annual labour requirement for pack management with the average number of cows housed in each barn showed that annual labour per cow was $4.2 \pm 2.1 \mathrm{~h} /$ cow/year (range 1.2-6.7 $\mathrm{h} /$ cow/year). Since the labour requirement for pack cultivation mainly depended on the surface area of the bedded pack, a significant relationship $\left(\mathrm{R}^{2}=0.505 ; \mathrm{P}=0.048\right)$ was found between the surface area per cow and the annual labour requirement for pack management (Figure 1).

\section{Bedding}

In this study, dry sawdust and wood shavings (mainly from pine wood) were used for CBPB bedding. Seven producers used only sawdust while 3 preferred a mixture of sawdust and wood shavings. During winter, one farmer tried to add a load of coconut fibre but he reported problems due to a rapid rise in moisture content that resulted in a consistent loss of structure. In warm periods, some producers successfully re-used sun-dried manure derived from CBPB. The amount of fresh bedding materials needed was $875.2 \pm 469.7 \mathrm{~m}^{3}$ /year (range $575-1600$ $\mathrm{m}^{3} /$ year). Annual bedding requirement compared with the bedded area surface and the number of cows housed in each barn was, respectively, $1.4 \pm 2.9 \mathrm{~m}^{3} / \mathrm{m}^{2} /$ year (range $0.3-2.6 \mathrm{~m}^{3} / \mathrm{m}^{2} /$ year) and $8.2 \pm 2.9 \mathrm{~m}^{3} /$ cow $/$ year (range $3.2-13.4 \mathrm{~m}^{3} / \mathrm{cow} / \mathrm{year}$ ). The amount of bedding, the frequency with which it was added, and the time between complete pack renovations strongly depended on the season and weather conditions. In all farms in the study, the consumption of bedding was concentrated in the winter period when there was little evaporation of water from the pack due to low air temperature and high relative humidity. Most of the dairies did not add any bedding to the pack in the period between May and late September. Although climate plays a major role, also the bedded surface area per cow affected the amount of bedding needed in CBPB. Increasing the bedded surface area meant a greater amount of bedding was used to start-up the pack. On the other hand, a larger surface area per cow meant consistently less bedding was needed during the subsequent phases. A tendency towards an inverse correlation $\left(\mathrm{R}^{2}=0.395 ; \mathrm{P}=0.051\right)$ was found between the surface area per cow and the annual amount of bedding used per cow (Figure 2).

\section{Pack temperature}

Pack temperature measured in the summer was $29.6 \pm 3.7^{\circ} \mathrm{C}$ (range 24.2-33. $4^{\circ} \mathrm{C}$ ) while air temperature inside the barn was $29.3 \pm 1.6^{\circ} \mathrm{C}$ (range $27.3-31.4^{\circ} \mathrm{C}$ ). In winter, pack temperature was $11.7 \pm 6.0^{\circ} \mathrm{C}$

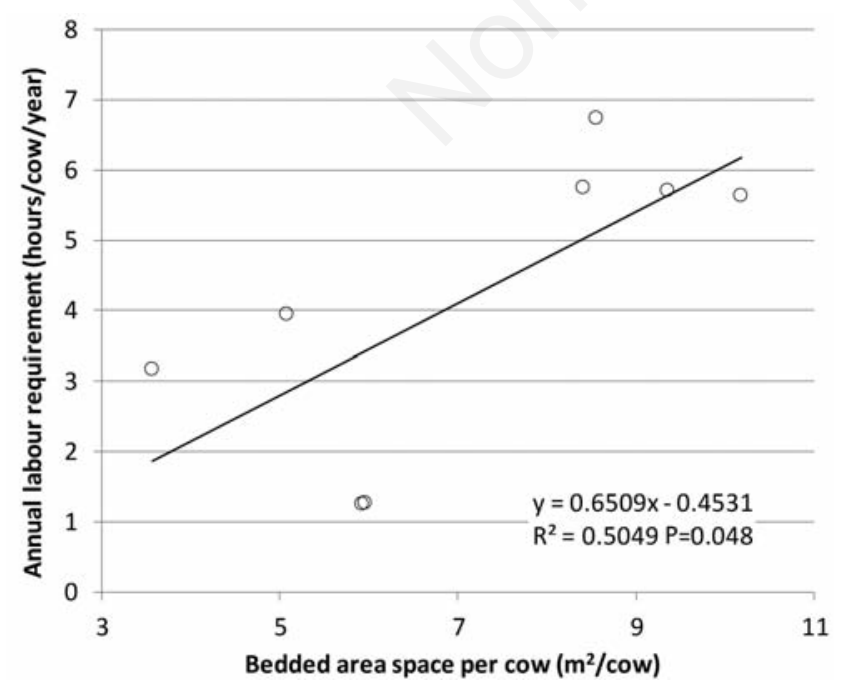

Figure 1. Scatter plot of the relationship between the bedded area space per cow and the annual labour requirement for pack management (data from 2 farms were not available).

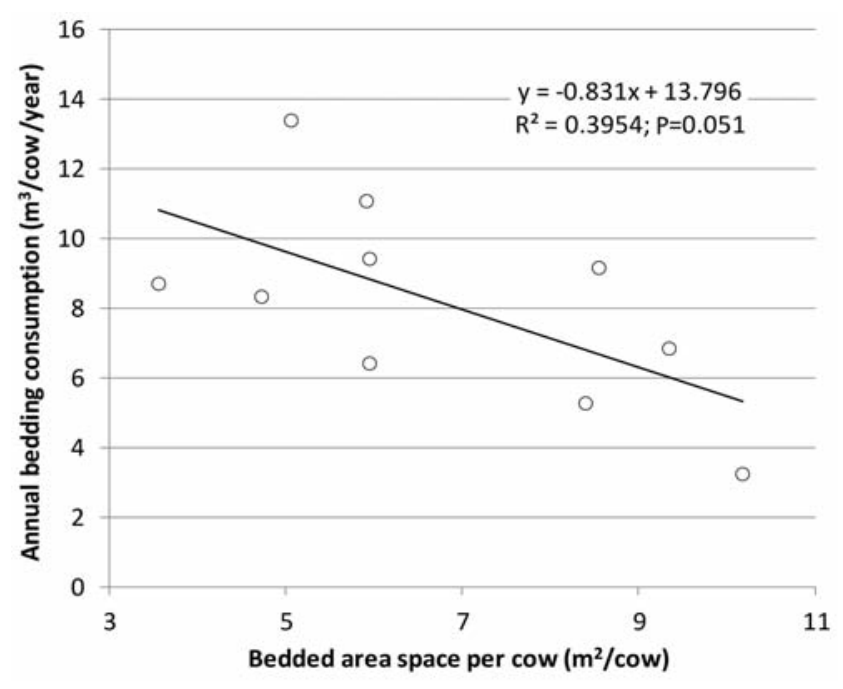

Figure 2. Scatter plot of the relationship between the bedded area space per cow and the annual amount of bedding used. 
(range $6.4-21.6^{\circ} \mathrm{C}$ ) while air temperature was $4.4 \pm 1.9^{\circ} \mathrm{C}$ (range 2.3$7.2^{\circ} \mathrm{C}$ ). Both in summer and in winter, pack temperatures were not high enough for a composting process to be identified. However, the difference between pack and air temperatures measured on some farms in winter seems to suggest that the pack was biologically active. Some farmers noticed a reduction in resting time during winter that was probably due to low pack temperature. In a few barns, especially during summer, pack temperature was lower than air temperature. This was probably due to the intense evaporation of water from the pack's surface.

\section{Producers' satisfaction}

Overall, farmers were satisfied with CBPB. Almost all producers identified cow welfare and leg and feet health as the main benefits of this alternative housing system. High satisfaction levels were also found in terms of udder health, fertility and manure management. Many farmers spontaneously remarked on a reduced presence of flies in $\mathrm{CBPB}$, especially during the summer. Major concerns regarded ease of management and costs. Results of the survey on producers' satisfaction are summarised in Table 2.

\section{Discussion}

Most of the farmers interviewed shifted from deep straw-bedded yard to compost-bedded pack to reduce mastitis; the satisfaction level with regards to this suggests the objective was achieved. In dairies in the current study, herd mean SCC was $354,000 \pm 121,100$ cells/mL. Other studies on CBPB reported similar SCC. In a survey carried out in Kentucky, herd mean SCC was 318,000 cells/mL (Black et al., 2013). Barberg et al. (2007b) reported a mean SCC of 325,000 172,000 cells/mL for 12 herds housed in CBPB in Minnesota. In the same study, a reduction in mastitis infection rate was found in 6 out of 9 herds after shifting to CBPB. In contrast, Lobeck et al. (2011) compared welfare of dairy cows housed in CBPB and free stall barns and found no significant difference in mastitis infection rate. Although udder health in CBPB seems to be adequate, difficulties in keeping the pack dry could pose challenges in terms of cow cleanliness, especially during winter. Many Authors emphasised that high hygiene standards at milking and proper management of the pack are essential for achieving high milk

Table 2. Producers' satisfaction with compost-bedded pack housing system.

\begin{tabular}{lccc} 
& \multicolumn{3}{c}{$\begin{array}{c}\text { Satisfaction level* } \\
\text { Min }\end{array}$} \\
Animal welfare & 3 & 3.65 & 4 \\
Cow cleanliness & 2 & 3.00 & 4 \\
\hline Udder health & 3 & 3.25 & 4 \\
Claw and leg health & 3 & 3.50 & 4 \\
\hline Fertility & 2 & 3,13 & 4 \\
Longevity & 2 & 3.00 & 4 \\
\hline Milk yield & 2 & 3.00 & 4 \\
Ease of management & 2 & 2.88 & 4 \\
\hline Costs & 2 & 2.63 & 4 \\
Manure management & 2 & 3.25 & 4 \\
\hline
\end{tabular}

*Satisfaction reported on a 4-point scale from 1 (very dissatisfied) to 4 (very satisfied). quality in this housing system (Barberg et al., 2007b; Janni et al., 2007; Black et al., 2013).

Producers interviewed in the current study were generally satisfied with the welfare of cows housed in CBPB. Similarly, Minnesota dairy farmers identified animal welfare as the main reason to build a CBPB (Barberg et al., 2007a) and increased cow comfort compared to free stalls was the most frequently cited benefit of this alternative housing system among dairy producers in Kentucky (Black et al., 2013). Experimental data confirmed that CBPB have a positive impact on the welfare of dairy cows (Barberg et al., 2007b; Fulwider et al., 2007; Lobeck et al., 2011). However, many authors remarked that cost and availability of bedding could limit the use of CBPB (Barberg et al., 2007a; Shane et al., 2010), an issue about which Italian producers have also quite clearly expressed their concern.

In the CBPB included in the current study, the annual amount of bedding used was $8.2 \mathrm{~m}^{3} / \mathrm{cow} / \mathrm{year}$. Considering an average cost for dry sawdust of $18 € / \mathrm{m}^{3}$, the annual bedding cost was $148 € /$ cow/year. Janni et al. (2007) estimated an annual bedding consumption in Minnesota CBPB of $19.6 \mathrm{~m}^{3} / \mathrm{cow} / \mathrm{year}$ and a total annual bedding cost of 181 $\$ /$ cow/year. Although the annual cost for bedding was similar, the amount of bedding used in Italian CBPB was significantly lower than that used in Minnesota. Climate and weather conditions could partially explain the amount of bedding needed but pack management and barn characteristics are also to be considered.

Many Authors consider the space per cow as a key factor in CBPB management (Klaas and Bjerg, 2011). Janni et al. (2007) recommended a minimum pack surface area per cow of $7.4 \mathrm{~m}^{2} / \mathrm{cow}$ for a $540 \mathrm{~kg}$ animal. More recently, researchers from Kentucky suggested that the optimal surface area per cow ranges from $9.3 \mathrm{~m}^{2} /$ cow to $10.2 \mathrm{~m}^{2} /$ cow (Black et al., 2013). Considering only the bedded area, the space allocation in CBPB included in the current study was $6.8 \pm 2.2 \mathrm{~m}^{2} / \mathrm{cow}$. Since an inverse relationship was found between the space per cow and the amount of bedding used per cow (Figure 2), increasing the space per cow should result in lower bedding consumption. In fact, considering only the barns that had over $8 \mathrm{~m}^{2} / \mathrm{cow}(\mathrm{n}=4)$, the average annual amount of bedding used and the annual cost for bedding were 3.0 $\mathrm{m}^{3} /$ cow/year and $54 € /$ cow/year, respectively. On the other hand, greater space per cow may result in an increase in labour requirement and in added costs for barn building. The productivity of pack stirring operations varied considerably among farms in the study (range 725$8006.5 \mathrm{~m}^{2} / \mathrm{h}$ ). Producers reported that shape and dimensions of the barn, as well as the presence of fences and gates, strongly affected the amount of time needed to stir the pack. Bedded areas with a regular shape minimised the time required to aerate the pack.

The space per cow and the shape of the bedded area can significantly affect the cost of CBPB management. However, pack temperature should also be taken into account. The heat produced by the microbial activity within the pack increases water evaporation and thus reduces the amount of bedding needed to keep the pack dry (Janni et al., 2007). Smits and Aarnink (2009) calculated that the evaporation of water from bedding which is effectively composting is higher than that from a noncomposting pack. Black et al. (2013) found that in Kentucky CBPB the ideal pack temperature is between $43^{\circ} \mathrm{C}$ and $60^{\circ} \mathrm{C}$. Nevertheless, high pack temperatures seem to be necessary only in CBPB with relatively high animal density (7.5-12.5 m²/cow) and in cold climates, especially during winter. In Israeli climatic conditions, providing each cow with a space of at least $15 \mathrm{~m}^{2}$ meant it was possible to keep the pack dry throughout the whole year, even though heat generation was limited (Klaas et al. 2010). In CBPB in the current study, pack temperatures (winter: $11.7 \pm 6.0^{\circ} \mathrm{C}$; summer: $29.6 \pm 3.7^{\circ} \mathrm{C}$ ) and the bedded area per cow $\left(6.8 \pm 2.2 \mathrm{~m}^{2} / \mathrm{cow}\right)$ do not seem to be sufficient to allow adequate evaporation from the pack, especially during winter.

Low bacterial activity in the pack could be explained by high animal 
density that leads to excessive bedding moisture content and thus limits the growth of aerobic bacteria. In order to ensure that the heat produced in the pack is not lost, relatively high pack depth is needed. Experience in the Netherlands indicated that a layer of at least $50 \mathrm{~cm}$ is needed to avoid excessive heat dissipation during pack stirring (Galama, 2011). In addition, higher pack depth allows manure to be stored in the barn for longer periods of time, thus reducing the need for external storage and the labour required for pack renewal. In CBPB in the current study, pack depth ranged from $15 \mathrm{~cm}$ to $40 \mathrm{~cm}$. Most producers reported problems in increasing the pack depth because the bed moisture content increased too rapidly and cows sunk deep into it.

Some farmers noticed a reduction in cow resting time during winter that is probably due to the excessive moisture and the low temperature of the pack. This is in contrast with behavioural data obtained in free stall barns where resting time is longer in winter than in summer (Barbari et al., 2012). In Italian CBPB, lower animal densities seem to be needed to maintain adequate pack moisture content and reduce the amount of bedding required, especially in winter. Further studies are needed to identify the optimal space per cow, monitor gaseous emission from the pack, and develop management recommendations for CBPB in Italian climatic conditions.

\section{Conclusions}

Compost-bedded pack barns, if properly managed, could represent an effective solution for housing dairy cows also in Italy. Producers identified animal welfare as the main benefit of this system and overall they appeared to be very satisfied. Nevertheless, concerns about the cost of bedding seem to suggest that pack management and barn characteristics have not yet been optimised. Results obtained in this survey confirmed that animal density is a key factor in compost-bedded pack barns.

\section{References}

Barberg A.E., Endres M.I., Janni K.A. 2007a. Compost dairy barns in Minnesota: a descriptive study. Appl. Eng. Agric. 23:231-8.

Barberg A.E., Endres M.I., Salfer J., Reneau J. 2007b. Performance and welfare of dairy cows in an alternative housing system in Minnesota. J. Dairy Sci. 90:1575-83.

Black R., Bewley J., Taraba J., Day G., Damasceno F.A. 2013. Kentucky compost-bedded pack barn project. Cooperative extension service,
University of Kentucky, College of agriculture, Lexington, KY, USA.

Barbari M., Leso L., Rossi G., Scaramelli A., Simonini S. 2012. Influence of Cooling Systems on the Behaviour of DairyCows Housed in Cubicle Barn. J. Agric. Sci. Technol. 1:40-9.

Enders M.I., Barberg A.E. 2007. Behaviour of dairy cows in an alternative bedded-pack housing system. J. Dairy Sci. 90:4192-200.

Fulwider W.K., Grandin T., Garrick D.J., Engle T. E., Lamm W. D., Dalsted N. L., Rolling B. E. 2007. Influence of free-stall base on tarsal joint lesions and hygiene in dairy cows. J. Dairy Sci. 90:3559-66.

Galama P. 2011. Prospects for bedded pack barns for dairy cattle. Wageningen UR Livestock Research, Lelystad, The Netherlands.

Janni K.A., Endres M.I., Reneau J.K., Schoper W.W. 2007. Compost dairy barn layout and management recommendations. Appl. Eng. Agric. 23:97-102.

Klaas I.C., Bjerg B. 2011. Compost barns - an alternative housing system for dairy cows? CAB Rev. Perspect. Agric. Vet. Sci. Nutr. Nat. Resour. 45:1-9.

Klaas I.C., Bjerg B., Friedmann S., Bar D. 2010. Cultivated barns for dairy cows - an option to promote cattle welfare and environmental protection in Denmark? Dansk Veterinærtidsskrift. 93:20-9.

Leso L., Uberti M., Barbari M. 2013. Compost barn, una soluzione amica del benessere. L'allevatore Magazine. 11:38-46.

Lobeck K.M., Endres M.I., Shane E.M., Godden S.M., Fetrow J. 2011. Animal welfare in cross-ventilated, compost-bedded pack, and naturally ventilated dairy barns in the upper Midwest. J. Dairy Sci. 94:5469-79.

Ofner-Schröck E., Zähner M., Huber G., Guldimann K., Guggenberger T., Gasteiner J. 2013. Kompoststall - funktionell und tiergerecht? Bautagung Raumberg-Gumpenstein. 2013:15-22.

R Development Core Team. 2011. R: A language and environment for statistical computing. R Foundation for Statistical Computing, Vienna, Austria. Available from: http://www.R-project.org/

Shane E.M., Endres M.I., Janni K.A. 2010. Alternative bedding materials for compost bedded pack barns in Minnesota: a descriptive study. Appl. Eng. Agric. 26:465-73.

Smits M.C.J., Aarnink A.Y.A. 2009. Verdamping uit ligbodems van vrijloopstallen; oriënterende modelberekeningen. Rapport 230. Wageningen UR Animal Sciences Group, Lelystad, The Netherlands.

Van Dooren H.J., Galama P., Smits M., Ouweltjes W., Driehuis F., Bokma S. 2012. Bodems voor vrijloopstallen. Rapport 411. Wageningen UR Livestock Research, Lelystad, The Netherlands.

Ventura P.G. 2011. Un modello innovativo per le stalle europee. Stalle da latte. 29:30-2.

Vighi P., Uberti M., Calamari L. 2009. Più benessere per le bovine con l'erpicatura della lettiera. Terra e Vita 24:43-6. 